\title{
Point-Counterpoint: Should Attendance Be Required In Collegiate Classrooms?
}

Jo Ann M. Pinto, Ph.D., Montclair State University, USA

Peter Lohrey, Ph.D., Montclair State University, USA

\begin{abstract}
This paper examines two divergent viewpoints about whether or not class attendance should be mandatory in higher education. The authors, both accounting professors at the same institution, delineate their respective viewpoints citing school policy, federal regulations and academic freedom as factors which motivate their attendance policy.
\end{abstract}

Keywords: Academic Policy; Time Management and Teaching Styles

\section{INTRODUCTION}

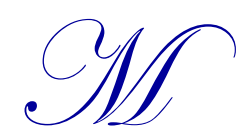
aking the transition from high school to college is challenging for many students. One of the key differences is the amount of time they are required to be physically in an academic setting. High school students spend approximately 32 hours per week within school facilities, and attendance is mandatory. In fact, skipping class can result in after-school detention or even suspension. College students, on the other hand, typically spend between 12 and 15 hours per week in class (this may vary by discipline with science and engineering students spending many more hours in laboratory classes). Attendance may not always be mandatory or even documented.

The question this paper seeks to address is, similar to what students experience in a K-12 setting, "should attendance also be mandatory on the college campus?" We tackle this question first by exposing the position of one faculty member who strongly affirms this policy and follow-up with an equally passionate advocate of student free choice regarding this matter. This paper concludes with a reconciliation of the opposing viewpoints.

Before we begin our debate a brief note on style is warranted. Throughout this paper the pronouns "he" and "she" are utilized; their usage does not pertain to a single person or sex.

\section{MAKE CLASS ATTENDANCE MANDATORY IN MOST SITUATIONS}

\section{A. School Policy}

Some time ago this academic tried, unsuccessfully, to create a departmental policy regarding attendance for accounting majors. The consensus in the department was that, in the spirit of academic freedom, this decision is best left to individual faculty members. Before our faculty meeting, our department researched the University's attendance policy. It states, "Students are expected to fulfill all course requirements, and although attendance is not always mandatory, it is desirable." In essence, our University also leaves attendance matters up to the faculty. Exercising academic freedom, this professor has, for a very long time, made attendance a significant portion of a student's overall grade.

\section{B. Preconditions for an Attendance Policy}

This professor works at a university where small class sizes are the norm. During a recent semester, she taught four courses, two undergraduate and two graduate, where enrollments ranged between 26 and 32 students. This enrollment pattern represents a typical semester at our institution. The small class sizes contrasts with the conditions 
she encountered while earning a doctorate at a major research university: some of the classes under her instruction were in auditoriums where close faculty-student interactions were not possible.

In our current setting, she establishes attendance policy on day one. In a very low-tech approach, each student fills out one side of a color-coded index card (one color for each class) with their name and contact information. These cards are used to call attendance at the beginning of each class and mark the back with the dates they are absent. As a side benefit, the instructor gets to know the students' names a few weeks into the semester. Prior research (Ricci, 2004) has shown there is a positive relationship between student satisfaction with the course and the ability of the instructor to recall the student's name. Additionally, this acquaintance with student names comes in useful when, what could be several semesters later, students request recommendation letters for scholarships, employment or graduate school.

\title{
C. Benefits of an Attendance Policy
}

Although only anecdotal, this professor has gleaned a correlation between class attendance and final grade. Part of the reason is that $10 \%$ of students' final grade at the undergraduate level and $15 \%$ at the graduate level is determined by attendance and participation. A student with a good attendance record can usually see half a letter grade improvement in their final grade over their exam average. More importantly, however, is the adage that showing up is $90 \%$ of life. It goes without saying that missing out on critical lectures and homework recitations along with case studies and group problem-solving will almost certainly impact exam performance.

As an Accounting professor, this academic is not only imparting students with content but also preparing them for the profession. In just a few short years they will have to be accountable for their time in a major way and time management skills are paramount in the field. This instructor believes she is already making an impact on how students behave. When they do miss class, usually for a good reason, they send e-mails explaining their situation. Also, they usually also ask how they can make up the work they are missing. Compliance with attendance policies is high.

Finally, to comply with Federal student loan information, professors are required to submit student attendance records at a census date several weeks into the semester to the Provost's office. If attendance was not carefully tracked, it would be difficult if not impossible to supply data for regulatory purposes which could ultimately put student financial aid in jeopardy.

\section{Concluding Comments}

This professor will sum up her comments by these few lines of a poem shared by a colleague many years ago regarding class attendance:

\section{Tom Wayman (1993), Harbour Publishing Did I Miss Anything? (Used with copyright permission)}

\author{
Nothing. None of the content of this course has value or meaning \\ Take as many days off as you like: \\ any activities we undertake as a class \\ I assure you will not matter either to you or me \\ and are without purpose
}

As Wayman points out, this may be the perception of some students. However, it is our job as faculty members and role models to impart upon students the relevance and benefits of attending as many classes per semester as possible. 


\section{MAKE CLASS ATTENDANCE VOLUNTARY IN MOST SITUATIONS}

\section{A. School Policy}

This professor teaches at the same university in the same department and he just finished his first year at the institution. He strongly agrees with the University's attendance policy which states, "Students are expected to fulfill all course requirements, and although attendance is not always mandatory, it is desirable." $\mathrm{He}$ is also glad that the University leaves attendance matters up to the faculty.

\section{B. Preconditions for an Attendance Policy}

During the fall semester of 2014 , this professor taught four courses, all of which were undergraduate, where enrollments ranged between 27 and 30 students. The small class sizes provide a different setting from the one he operated in when he first started his teaching career. He earned his doctorate at a major research university, where most of the classes he taught were at the graduate level - with approximately 30 to 35 students. There was a close faculty-student interaction throughout - but only when the students sought it.

In this academic's current setting, he doesn't establish any attendance policy - except for tests, where students must attend to take an exam. He has students fill out a biography sheet which provides their name, age, and educational background - including prior courses in accounting which they have taken, their job background, and their email address. He uses these sheets to call randomly on students during lectures and problem-solving exercises. All of his class time focuses on lectures and discussions.

He gets to know all of their names this way, as some students tend to volunteer answers more often than others. Prior research has shown varied results (Robert, 2007). Broder (1994) points out that, "The primary factor involving quality and clarity of lectures seem to support the need for educators to continually seek creative and innovative teaching methodologies to increase class attendance."

\section{Benefits of No Attendance Policy}

Even though this professor is presenting a subjective view at this point, he believes that there is a strong connection between class attendance and the quality of teaching by an instructor. He believes that it is his job to attract students to come to class, it is not to make them come to class. Many University students come from a wide variety of educational backgrounds, and as such, have a wide variety of classroom needs. Some students, who have already had a preliminary course in the subject matter that he teaches are at a distinct advantage, and therefore, do not need to be made to come to class.

He also believes that young men and women who are 18 years of age and older are adults. They can legally vote, and they can be legally drafted into our Armed Forces - if Congress decided to do so. Many of them no longer live at home, and they are now on their own. As a matter of a fact, the average age of college students has risen in recent years. $(\mathrm{http} / /$ nces.ed.gov/fastfacts/display.asp?id $=98)$.

As his colleague points out, "in just a few short years, they will have to be accountable for their time in a major way...." This researcher disagrees with this comment, for they are now accountable for their time in a major way. Just ask one of their parents who pay the tuition bill.

This instructor also receives emails from students when they miss class, and to be honest, he doesn't really have the time to read them. He holds his students to be accountable unto themselves, and not to him. If they come to class it is because they want to, not because they have to.

This professor thinks the most accurate way to measure class attendance is to look at the teaching evaluations. He does not have any empirical evidence, but he believes there is a high a high correlation between class attendance,

${ }^{1}$ http://www.montclair.edu/dean-of-students/handbook/undergrad-policies/ 
student grades, and teaching evaluations. To not include an evaluation of teaching quality in this discussion would be a major mistake.

Finally, he points to a recent article on the front page of the NY Times entitled, "No Foul Mouths on This Field: Football With a New Age Twist". (NY Times, Sept. 6, 2015). The article talks about Seattle Seahawks coach Pete Caroll's philosophy on coaching an NFL football team. It points out that Pete Carroll has led the Seahawks for five years, and that he has made his mark not just by winning games but reshaping the role of N.F.L. coach. "Carroll, 63, has embraced diversity, encouraged free expression, promoted self-discovery and remained relentlessly positive."

One may wonder where Coach Carroll got his inspiration. It turns out that in 2013, he heard a speech by Angela Duckworth, a research psychologist at the University of Pennsylvania. She determined that differing levels of grit in the face of unfavorable odds explained why some talented people succeeded while similarly talented people failed. Duckworth states that "Most of these cases, it's about hanging in there when other people don't or won't..."

Gee, this professor wonders if that works in the classroom?

\section{SUMMARY}

This article provides an introduction to the research project that we are about to undertake. It contains each of the co-authors' opinions based on their individual experiences to date. We will follow this introduction with an article that will lay out our research design and the methodology that we will use to analyze our empirical results.

We hope that we will find concrete evidence to support or refute one of our views. A third and final article will be written to provide the results of our research, our interpretations of the outcomes, and suggestions for future avenues of testing to examine this ongoing dialogue.

\section{ATTENDANCE}

Students are expected to fulfill all course requirements, and although attendance is not always mandatory, it is desirable. Absence from laboratory or studio sessions shall be by agreement with the professor. Professors should notify the students, in writing, of what the course expectations may be regarding attendance. Professors may penalize the students for failure to meet specific attendance requirements.

Students who register are considered enrolled in their courses regardless of attendance. Students should ascertain attendance requirements at the onset of each course. Refer to the university catalog for specific guidelines.

\section{AUTHOR BIOGRAPHIES}

Peter Lohrey is an Assistant Professor in the Department of Accounting, Law \& Taxation at Montclair State University. He holds a B.S. in Business Administration from the University of Delaware, an MBA and M.S. in Finance from Loyola University in Maryland, and a Ph.D. in Accounting and Finance from George Washington University. His research interests are in the areas of fair value accounting, forensic accounting, business valuation and taxation. His publications have appeared in several academic and professional journals including, The Value Examiner, The Business Journal for Entrepreneurs, The International Journal of E-Business Research, and the Credit and Financial Management Review. Peter Lohrey, Ph.D., Montclair State University, 1 Normal Avenue, Montclair, NJ 07043 USA. E-mail: lohreyp@mail.montclair.edu.

Jo Ann Pinto is currently an Associate Professor in the Department of Accounting, Law \& Taxation at Montclair State University where she has been employed since 1999. She holds a B.S. in Accounting from Virginia Polytechnic Institute and State University, an M.A. in Economics and an MBA in Accounting from Montclair State University and a Ph.D. in Accounting and Applied Economics from Rutgers University.

Her research interests are in the area of capital markets, taxation and economic development. Her publications have appeared in The CPA Journal, The Journal of Applied Business Research and the Journal of 
International Financial Management and Accounting, among others. Her teaching responsibilities include financial accounting, cost accounting, managerial accounting and financial statement analysis. pintoj@mail.montclair.edu. Montclair State University, 1 Normal Avenue, Montclair, NJ 07043.

\section{REFERENCES}

Broder, J. (1994). Empiricism and the art of teaching. Journal of Agricultural and Applied Economics, 25, 1-18.

NY Times, Sept. 6, 2015, http://www.nytimes.com/2015/09/07/sports/football/no-foul-mouths-on-pete-carrolls-field-footballwith-a-new-age-twist.html?_r=0

Ricci, C. (2004). Impacts of a professor's knowledge of students' names: A study of undergraduate finance majors. Journal of Excellence in College Teaching, 15(3).

Robert, L. (2007). Class attendance: Is it important? Center for Teaching Excellence, United States Military Academy, West Point, N.Y.

Wayman, T. (1993). From Did I miss anything? Selected poems 1973-1993, Harbour Publishing. "In recent years, the percentage increase in the number of students age 25 and over has been larger than the percentage increase in the number of students..." http://nces.ed.gov/fastfacts/display.asp?id=98

http://www.montclair.edu/dean-of-students/handbook/undergrad-policies/ 


\section{NOTES}

